\title{
Turkey's Hasty Constitutional Amendment Devoid of Rational Basis: From a Political Crisis to a Governmental System Change
}

\author{
Dr. Peri Uran \\ Post-doctoral Research Fellow at Columbia University Law School \\ Jerome L. Greene Hall, 435 West 116th Street, NY 10027, USA \\ E-mail: puran@law.columbia.edu
}

I would like to thank Prof. Dr. Peter Strauss for not only giving me the opportunity to conduct my research at an excellent academic environment but also being a great supervisor to me.

\begin{abstract}
Governmental systems are one of the significant topics of constitutional law literature and comprehensive studies have been carried out on this issue. The answer to the question whether a parliamentary system, a presidential system or a mixed system is the most suitable system of government can change according to the political preferences of the countries. Since countries search for the best system of government, debate about "governmental system change" keep its actuality. (Note 1) Discussions about governmental system change are also not new in Turkey. Parliamentarism has been one of the defining characteristics of the Turkish constitutional system since 1876 Ottoman Constitution; however, during the application of the Constitution of 1982 first ex-president Turgut Özal, then ex-president Süleyman Demirel maintained that the governmental system in Turkey needed to be changed from parliamentary system to semi-presidential or presidential system, because Turkey's growing and pressing problems require an "effective executive" which would take necessary decisions quickly and apply them effectively and the president in such systems fits this requirement. Governmental system change issue also came into question during the The Justice and Development Party Government's term of office. Both the prime minister Recep Tayyip Erdoğan himself and the other senior party members occasionally mentioned that semi-presidential system would be the best governmental system for Turkey (Öder, 2005, p.31; Gönenç, 2008, p.522; Caniklioğlu, 1999, p.184-186; Yavuz, 2000, p.544-556; TBMMTD, 1999, p.28).

The crucial constitutional amendment which was accepted through a nationwide referendum on 21 October 2007, overshadowed the discussions about governmental systems in Turkey for awhile. The amendment in question changed the Turkish Governmental System from parliamentary system to parliamentary with "president" system by introducing the principle of "popular election of the president". (Note 2) Moreover, the new system is being considered as a step to pass through a semi-presidential or a presidential system in Turkey. Some academicians think that the adoption of the principle of popular election of the president was not the consequence of the discussions about a transition from the parliamentary system to a presidential or a semi-presidential system among political and academic circles. In fact, it was a reaction to a political crisis related to the election of the President by Turkish Parliament, therefore it is difficult to accept this amendment as a well designed constitutional engineering scheme and the new governmental system could create serious problems in the future. (Note 3)

In this article, the political crisis as the main reason of the last constitutional amendment in Turkey which introduced the principle of popular election of the president by parliament will be summarized and the prospective problems that would arise from the new governmental system will be discussed. The debates of whether the presidential or semi-presidential system is the most suitable option for Turkey or not will also be reviewed. We believe that summarizing the process before the last amendment would be illuminative to comprehend the reason for making the amendment in question.
\end{abstract}

Keywords: Governmental system debates, Political crisis in the Turkish Parliament, Reaction to the political crisis, Turkey's 2007 Constitutional Amendment

\section{From a Political Crisis to a Governmental System Change}

Ahmet Necdet Sezer's presidency ended in May 2007 and it was almost certain that the next president was going to be a member of the ruling party, The Justice and Development Party (AKP), since the political party in question held the 
majority in the parliament. The idea of a president from AKP triggered a reaction among secular groups on the ground that a president from AKP could be the symbol of islamization of state institutions and would damage Turkey by introducing islamic values into the secular Kemalist state. Mass meetings of secular groups came together in big cities to convey a message that AKP would have to search for consensus over the presidency rather than using its parliamentary dominance. Not only secular groups but also the military was included in sending out messages to AKP. On 12 April 2007, the Chief of General Staff Yaşar Büyükanıt stated that the armed forces was hoping the next president would be someone who would commit himself to the fundamental values of the republic including secularism, not only in words but also in substance at a conference. (Note 4) Because of the harsh reactions of the secular elites including senior army generals, AKP did not nominate the Prime Minister Recep Tayyip Erdoğan as the presidential candidate, but instead Abdullah Gül, Minister of Foreign Affairs at that moment, was nominated. (Note 5) Gül's candidacy did not appease secular forces as well, since he was connected with the Islamist "National Outlook Movement" and his headscarf wearing wife (Note 6) was also considered as an indicator of Gül's anti-secular worldview; however AKP still preserved Gül's candidacy. The first round of the presidential election was held on 27 April 2007; Gül could not acquire the support of the qualified majority of deputies. According to the article 102 of Turkish Constitution before it was amended (Note 7) the President of the Republic shall be elected by a two-thirds majority of the total number of members of the Turkish Grand National Assembly and by secret ballot; if a two-thirds majority of the total number of members (367 deputies) can not be obtained in the first two ballots, between which there shall be at least a three-day interval, a third ballot shall be held and the candidate who receives the absolute majority of votes of the total number of members should be elected President of the Republic.

After the first round, the main opposition party, Republican People's Party (CHP), applied to the Constitutional Court for the annulment of the ballot on the ground that the required quorum had not been present. According to the article 96 of the Constitution, the Assembly shall convene with at least one third of the total number of members, unless otherwise stipulated in the Constitution. (Note 8) CHP considered the election of the president as one of the exceptions stated on article 96 of the Constitution. According to CHP, the article 102 of the Constitution implied that a two-thirds majority of the total number of the members of Assembly were supposed to be present in the session of presidential election.

The most surprising event however, was a harsh declaration on the Official Website of the Office of the Chief of the General Staff stating that : "It should not be forgotten that the Turkish armed forces are a side in this debate and are a devoted defender of secularism....The Turkish armed forces will display their position and attitudes when it becomes necessary. No one should doubt that....." The declaration was seen as an "e-memorandum" by many academicians and politicians. (Note 9)

On April 30, 2007 the Constitutional Court declared its decision and determined that 367 deputies must be present for the first two rounds of the presidential ballot when electing the president. (Note 10) On May 6, 2007 the Turkish Assembly could not elect the president once again, because the required quorum which was stated by the Constitutional Court was not acquired. Since the Assembly had failed to elect a new president, early elections came into question. (Note 11) Meanwhile, AKP proposed a package of constitutional amnedments including the introduction of the popular election of the president, the reduction of the president's term of office from 7 years to 5 years, the reduction of parliament's term of office from 5 to 4 years and a clarification of the quorum of the Assembly. After the amnedments were passed by the Assembly, President Sezer returned them to the Assembly; however they were readopted. (Note 12) On June 18, 2007 Sezer signed the amendments for publication in the Official Gazette and submitted them to a referendum. He also applied to the Constitutional Court for the annulment of the package of amendments, but this time Constitutional Court rejected the application. (Note 13) The amendments were approved by a referendum. (Note 14) On 22.07.2007, early general elections were held and AKP won 46.5\% of the votes. On 14.08.2007 Abdullah Gül redeclared his candidacy. This time, AKP was more powerful and event though CHP members did not attend the session for the election of president, the Assembly was able to acquire the required two-thirds majority to convene and Abdullah Gül was elected as the president of Turkey on August 28, 2007.

As can be seen, Parliament's failure to elect a new president, Constitutional Court's controversial decision and military interventions into political process, deepened the tension between AKP and the secular elite. So, one may assert that the adoption of the principle of popular election of the president which has changed the governmental system from parliamentary system to parliamentary with president system involved in the amendment package as a reaction to the political crisis during the election of the president and it was not the consequence of a well judged constitutional step. According to our opinion, even if the amendment which changed the Turkish Governmental System was accepted as part of a well thought out constitutional engineering design, it might still create serious problems in the future.

Before starting to state these prospective problems, it would be appropriate to define parliamentary with president system in general. In this system, the executive authority is completely dependent upon parliamentary confidence and the president is elected by the people but his legislative (Note 15), appointive and emergency powers are much more limited than the powers of a president serving under presidential or semi presidential constitution. Even though it has 
similar characteristics with a parliamentary system (Note 16), it can not be accepted as a type of parliamentary system since the president in this system is elected by the people. (Note 17) The problems that might occur from the new governmental system are underlined by some academicians. (Gönenç, 2007, p.39-43) According to their evaluation whom we also agree with, in a parliamentary with president system, not only the political party which competes with the others to have seats in the parliament and achieves majority in the parliament and controls the government after the competition, but also the president puts forward a political program and makes promises, do propogandize during the campaign in order to get elected. When the president, government and the majority of the parliament share the same worldview, these actors cooperate with each other to implement the same political program presumably; however this may hamper the impartiality of the president in favour of the ruling worldview. On the contrary, when these actors have different worldviews, in this case the principle of the unity of the political program is out of question. Both the president and the ruling political party put forward different political programs and the activities that they promised to fulfill whenever they come into power reflect different worldviews. The competing political parties can use the majority of the parliament and government authority in order to fulfill their political programs whenever they come into power, but how is a president in a parliamentary with president system able to fulfill his promises when he is elected? As underlined above, in a parliamentary with president system, the president holds highly limited powers even though he is elected by the people. In such a system, the legislative authority of the president should be increased, at least the power of proposing bills should be given to the president. The right to legislative initiation potentially strengthens the president's control over policy issues. Otherwise the president may enforce his constitutional authorities in order to fulfill his electoral promises. Moreover, a president who would like to fulfill his promises may put aside his impartiality. In other words, the president may be in need of seeking support in the parliament or he may tend to make an alliance with political parties in order to fulfill his electoral promises. In fact, the president may even cooperate with the opposition party in order to dismiss the government which does not share the same worldview with himself. It is not difficult to predict how such tendencies could damage the impartiality of the president. Above all, the competing political programs may cause a legitimacy crisis. In a parliamentary with president system, both the president and the legislature are directly elected by people and thus have separate sources of legitimacy; so there is always the possibility of deadlock and political paralysis when these actors have different worldviews and different political programs. (Gönenç, 2007, p.39-43) In brief, the new system in Turkey may cause considerable problems in the future, specifically when the president and government-parliament majority have different worldviews.

\section{Is Parliamentary with President System the Final Choice for Turkey?}

As mentioned at the beginning of this article, the parliamentary with president system is being considered as a step to pass through a semi-presidential or a presidential system in Turkey, so the new governmental system probably will not be the last experience for Turkey, however it should be remembered that similar problems can arise from semi-presidential and presidential systems in the long run, if they are adopted in Turkey.

In a common way semi-presidentialism is defined as a situation where there is a directly elected president and a prime minister and cabinet who are responsible to the legislature. (Elgie, 2005, p.98-112; Skach, 2005; Shugart, 2005, p.323-351) (Note 18) There is a widespread consensus that the direct election of the president can encourage the personalization of the political process and encourage the president to ignore any opposition. Linz argues that semi-presidentialism in which the president has considerable powers can turn to "a constitutional dictatorship" (Linz, 1994, p.48) When we consider the constitutional history of Turkey, we can clearly see that its presidents have always been stronger than presidents in the classical parliamentary systems. By referring to this consideration, it can be asserted that a Turkish president serving under a semi-presidential constitution presumably would have quite considerable powers and the combination of a president with strong constitutional powers supported by a parliament majority and a prime minister could encourage the president to ignore the rule of law. As Lijphart points out, semi presidential systems "actually make it possible for the president to be even more powerful than in most pure presidential systems". (Lijphart, 2004, p.102)

When the majority in the parliament is opposed to the president, in other words, when the president and the parliamentary majority have different worldviews, there is always a probability of controversy between these actors. Supposing that neither the president, nor the prime minister is willing to compromise, in this case a deadlock of the political system is inevitable. The problem of a divided executive defined as cohabitation, is the most well known argument against semi presidential system. The only instrument to overcome the cohabitation is compromising; however it is indeed uneasy to overcome such a gridlock for the countries that lack the culture of compromise. For example, such a cohabitation situation ended up with a military intervention in Chile in 1973. According to Faundez, in the event, government and opposition did not agree and as the political confrontation became more acute, with the government refusing to revoke its administrative orders and the opposition demanding the resignation of Allende, the military finally stepped in and staged a coup that brought down the popular Unity Government and democracy. (Faundez, 1997, p.317) 
Divided minority government in which neither the president, nor the prime minister, nor any party or coalition, enjoys a substantive majority in the legislature, is identified as another argument against semi-presidentialism" (Skach, 2005, p.15) It is alleged that this situation can predictably lead to an unstable scenario, characterized by shifting legislative coalitions and government reshuffles, on the one hand, and continuous presidential intervention and use of reserved powers, on the other (Skach, 2005, p.17-18) When the executive is weakened, because of the absence of a stable parliamentary majority, directly elected presidents may assert their power over the system and this weakens the democratization process. (Skach, 2005, p.18)

Both the arguments against semi-presidentialism in the name of dual legitimacy and over presidentialization are similar to criticisms of presidentialism. In presidential systems a president with considerable constitutional powers is directly elected by the people for a fixed term and is independent of parliamentary votes of confidence. The president is not only the holder of executive power but also the symbolic head of state and can be removed between elections only by impeachment. (Note 19) In presidential systems since both the president and legislature "derive their power from the vote of the people in a free competition among well defined alternatives, a conflict is always latent and sometimes likely to erupt dramatically; there is no democratic principle to resolve it" (Linz, 1994, p.7). In regard to over presidentialization, the perception of being of the representative of the whole nation may encourage the president to ignore the opposition. This argument is stressed as "The feeling of having independent power, a mandate from the people ... is likely to give a president a sense of power and mission that might be out of proportion to the limited plurality that elected him. This in turn might make resistances he encounters . . more frustrating, demoralizing, or irritating than resistances usually are for a prime minister." (Linz, 1994, p.19)

The rigidity of presidentialism, created by the fixed term of office which can be a liability is accepted as another argument against presidential system. This argument is also emphasized as "entails a rigidity . . that makes adjustment to changing situations extremely difficult; a leader who has lost the confidence of his own party or the parties that acquiesced in his election cannot be replaced." (Linz, 1994, p. 9-10)

Among these arguments against presidentialism, maybe the most criticisized one is "zero sum presidential elections". According to Linz, presidentialism is ineluctably problematic because it operates according to the rule of "winner-take-all", an arrangement that tends to make democratic politics a zero-sum game, with all the potential for conflict such games portend. (Linz, 1990, p.56) It is stated that in the American Presidential electoral process, the laws governing the selection of presidential electors in the States generally provide for the winner-take-all principle. This means that the winner of the popular vote in a State is usually awarded the votes of all of the electors that are allocated to that particular State. Consequently, even in a normal presidential election, the winner-take-all scheme can produce a substantial disparity between the popular vote and the electoral college vote. This has in fact happened. Indeed, it happened in the 2000 Presidential Election. Gore, the winner of the nationwide popular vote, failed in the end to gain a majority of the electoral college vote. (Tillers, 2002, p.50)

Linz underlines the danger of zero-sum presidential elections as "The danger that zero-sum presidential elections pose is compounded by the rigidity of the president's fixed term in office. Winners and losers are sharply defined for the entire period of the presidential mandate. There is no hope for shifts in alliances, expansion of the government's base of support through national-unity or emergency grand coalitions, new elections in response to major new events, and so on. Instead, the losers must wait at least four or five years without any access to executive power and patronage. The zero-sum game in presidential regimes raises the stakes of presidential elections and inevitably exacerbates their attendant tension and polarization." (Linz, 1990, p.56) If, in ethnically divided societies, a president belongs to one ethnic group, then the situation will be more hazardous. Ethnically divided societies need peaceful coexistence among contending groups. This requires compromise and conciliation. For that reason, it is absolutely necessary for representatives of these groups to be included in the decision -making process. However, in presidential systems, because of the rule of "winner - take -all," consensus and power - sharing mechanisms cannot work. (Lijphart, 1991, p.81)

When we consider the evaluations about semi-presidential and presidential systems above, the whole picture shows us that the systems in question may not be the appropriate options for Turkey as well as parliamentary with president system. First of all, it must be underlined that "a popularly elected president" can bring serious problems for Turkey in the long run. In the Ottoman Empire individuals lived in a society in which the Sultan had absolute powers with no tradition concerning the limitation of political power. During modern Turkish period, presidents have always been stronger than presidents in the classical parliamentary systems. As Heper states, the parliamentary system of government with a more than symbolic president proved to be rather problematic in Turkey. Turkish political actors could not appreciate the need for this type of political structuring. Özal and Demirel presidencies constituted the real test cases for the operation of parliamentarism with a more than symbolic presidency. Especially, ex-president Özal wanted to dominate the political system and resorted to a one-man show. As the nominal head of executive, he attempted to dictate policies to governments. His activist approach created tensions in the polity. (Heper, 1996, 
p.501-502) By considering the constitutional history of Turkey, it is not very difficult to predict what will happen when the president is elected popularly and represents the same majority in the legislature. In this situation the fundamental rights of the individuals will be in jeopardy. When the president lacks a parliamentary majority, then the conflict between the legislature and the executive will be more grave because of the absence of tradition of compromise and conciliation.

The reason why the governmental system in Turkey needed to be changed from parliamentary system to semi presidential or presidential system has been explained by the arguments of "instability" and "inefficiency" of Turkish parliamentarism. According to these arguments, Turkey has been administered by unstable and ineffective coalition governments for years; however only stable and effective governments can certainly ease the consolidation of democracy in Turkey.

The negative sides of Turkish parliamentarism can not be avoided; however in our opinion, it would have been more appropriate to rationalize Turkish parliamentarism with efficient institutional remedies than to adopt a new governmental system which is unfamiliar to Turkish constitutional experience.

\section{Rationalized Parliamentarism: An Ignored Remedy for Turkey?}

What could have been done in order to eliminate negative sides of Turkish parliamentarism? It is emphasized that, the fact that cabinets depend on majority support in parliament and can be dismissed by parliamentary votes of no-confidence may lead to cabinet instability and as a result, regime instability. The position of cabinets vis-a-vis legislatures can be strengthened by constitutional provisions designed to this effect. One such provision is the constructive vote of no confidence, adopted in the 1949 constitution of West Germany, which stipulates that the prime minister (chancellor) can be dismissed by parliament only if a new prime minister is elected simultaneously. This eliminates the risk of a cabinet being voted out of office by a "negative" legislative majority that is unable to form an alternative cabinet. (Lijphart, 2004, p.103) According to the article 67 of Basic Law for the Federal Republic of Germany, no chancellor may be removed unless a majority is able to name a successor. In our opinion, the adoption of the constructive no-confidence vote (Note 20) which can be accepted as the most effective rationalized parliamentarism (Note 21) device could have been put into effect in Turkey in order to reduce the possibility of potential governmental instability. (Note 22)

The Turkish Constitution of 1982 empowers the president to call new elections under two circumstances: 1. In cases where the Council of Ministers fails to receive a vote of confidence or is compelled to resign by a vote of no confidence, and if a new Council of Ministers can not be formed within forty-five days or the new Council of Ministers fails to receive a vote of confidence; 2. If a new Council of Ministers can not be formed within forty-five days after the resignation of the Prime Minister without having been defeated by a vote of confidence, or within forty-five days of the elections for the Bureau of the Speaker of the newly elected Assembly. In either case, the President, after consultation with the Speaker of the Assembly, may call new elections (Article 116). The power thus granted to the President aims to ensure governmental stability; however, in our opinion if the time period of 45 days had been reduced, a cabinet crisis could have been resolved in shorter time and the governmental stability could have been preserved in this way. (Onar, 2005, p.103)

As mentioned before, in the Turkish parliamentary government system the presidents appear stronger and more active than the presidents in classical parliamentary systems. It is stated that, not only the inherent logic of Turkish Constitutions, but also environmental factors and the personalities of the presidents contributed to making the president relatively strong. (Gönenç, 2008, p.503) The power of presidents has been discussed and criticized under various circumstances in Turkey. Even Ahmet Necdet Sezer, who was the most active president in the Turkish constitutional history in terms of using his constitutional powers (Note 23), stated that the powers given to the president by Article 104 far exceed the limits of a parliamentary democracy. Yet, it is unacceptable for an unaccountable president, from outside parliament, which represents the will of the nation, to share in running the country and to use special powers by himself. (Note 24) Sezer's term of presidency was full of political crises. The crises during the coalition governments triggered the governmental instability in Turkey. As an efficient remedy, the powers given to the president by article 104 of the Turkish Constitution of 1982 could have been limited in order to be compatible with parliamentary systems. Such an arrangement could also have reduced the possibility of potential governmental instability. (Onar, 2005, p.103)

The issue of European Union Membership is undoubtly one of Turkey's most important foreign policy problems. Turkey was officially recognized as an EU candidate in December 1999, and in December 2002 the European Council announced that if Turkey met its political 'Copenhagen' criteria by the end of 2004 it would open negotiations without delay. Since 1999, and particularly since the election of the AKP government in November 2002, there has been radical and rapid political reform in Turkey. European Union's assessments and reactions concerning a governmental system change in Turkey must be considered by Turkish political actors as well. Among the members of the Union, parliamentary system is accepted as the main governmental system. European Union's historical background, socio-economic and cultural structure makes it impossible to adopt presidential system, while semi-presidential system 
can be seen as an exception. However, the members which have adopted semi-presidential systems come face to face with serious political problems too often. (Elgie, 1999, p.26) When the constitutional history of Turkey is taken into consideration, it can easily be asserted that, the amendment changed the Turkish Governmental System from parliamentary system to parliamentary with "president" system by introducing the principle of "popular election of the president", will probably be critized, at least it will not be welcomed by European Union in the long run.

\section{Conclusion}

Governmental system change can not be seen only as a Constitutional Law issue. It would be inappropriate to discuss such a change without considering its effects on the whole legal system. According to Kelsen's theory, a legal system is made of a hierarchy of norms. Each norm is derived from its superior norm. (Kelsen, 1967; Marty, 2002, p.57) A norm change on the top of the pyramid definitely effects the norms at the bottom. In a similar vein, Krasner states that institutionalization can be conceived of along two dimensions, breadth and depth. Breadth refers to the number of links an institution has. Horizontal linkage refers to the density of links between a particular activity and other activities. If a particular activity is densely linked, then one modification requires changes in many others. (Krasner, 1988, p.75-76) In the light of these theoretical expansions, it may be accepted that, when a change occurs in the governmental system, the whole legal system should be reviewed and a platform which is adaptable to the new system should be built momentously. However, when the amendment process in Turkey is considered, it can be clearly recognized that neither the constitutional system was revised nor a platform which is adaptable to the new governmental system was built before the last constitutional amendment, that changed the governmental system, was accepted.

Lindner indicates that, the political costs of institutional reform (switching costs) plays an important role in stabilizing the existing institutional path. Even though actors accept that reform is necessary, the switching costs and the uncertainty over the gains from a new system (opportunity cost) prevents change. (Lindner, 2003, p.924; Pierson, 2000, p.251-267) This particular point was also not considered by political actors in Turkey during the amendment process, therefore, if the political costs of the governmental system change in Turkey exceeded the gains from the new governmental system, this would not be surprising.

As Lipset has pointed out, it is difficult, if not impossible, to change culture. Historical legacies do not disappear overnight. Nevertheless, it is much easier to modify political institutions than adopt a new system. (Lipset, 1990, p.83) So, ignoring the devices to rationalize Turkish parliamentarism and adopting a new governmental system by introducing the principle of "popular election of the president" which might bring serious problems in the future may be the biggest regret of Turkish political actors in the long run.

\section{References}

Bahçeci, B. (2008). Karşılaştırmalı Hukukta ve Türkiye'de Devlet Başkanının Veto Yetkisi (President's Veto Power in Comparative Law and in Turkey). Ankara: Yetkin Publishers.

Caniklioğlu, M. (1999). Türkiye'nin Sistem Sorunu mu Var? (Does Turkey Have a System Problem?). Kamu Hukuku Arşivi (Public Law Archive), 2 (3),184-186.

Colomer, J. M. (1996). Political Institutions in Europe. London and New York: Routledge.

Duverger, M. (1980). A New Political System Model: Semi-presidential Government. European Journal of Political Research, 8 (2), 165-264.

Elgie R. (1999). Semi- Presidentialism in Europe, Robert Elgie (ed). Oxford University Press.

Elgie, R. (2005). A Fresh Look at Semi-Presidentialism Varieties on a Theme. Journal of Democracy, 16 (3), 98-112.

Faundez, J. (1997). In Defense of Presidentialism: The Case of Chile, 1932-1970. In S. Mainwaring and M. Shugart (eds), Presidentialism and Democracy in Latin America. Cambridge University Press, p. 317.

Gönenç, L. (2007). Hükümet Sistemi Tartışmalarında Başkanlı Parlamenter Hükümet Sistemi Seçeneği (Parliamentary with President System Option on Debates over Governmental System ). Güncel Hukuk, 44, 39-43.

Gönenç, L. (2008). Presidential Elements in Government: Turkey. European Constitutional Law Review, 4 (3), 488-523.

Heper, M. \& Çınar, M. (1996). Parliamentary Government with a Strong President: The Post 1999 Turkish Experience. Political Science Quarterly, 111(3), 483-503.

Kelsen, H. (1967). Pure Theory of Law (Translated by Max Knight). California: University of California Press.

Krasner, S. D. (1988). Sovereignty: An Institutional Perspective. Comparative Political Studies, 21(1), p. 66-94.

Lijphart, A. (1991). Constitiutional Choices for New Democracies. Journal of Democracy, 2(1), 73-84.

Lijphart, A. (1992). Introduction. In A. Lijphart (ed.), Parliamentary versus Presidential Government. Oxford: Oxford University Press, p. 2-3. 
Lijphart, A. (1999). Patterns of Democracy: Government Forms and Performance in Thirty-Six Countries. New Haven, CT: Yale University Press.

Lijphart, A. (2004). Constitutional Design for Divided Societies. Journal of Democracy, 15(2), 97-109.

Lindner, J. (2003). Institutional Stability and Change: Two Sides of the Same Coin. Journal of European Public Policy, 10(6), 912-935.

Linz, J. (1990). The Perils of Presidentialism. Journal of Democracy, 1(1), 52-69.

Linz, J. (1994). Presidential or Parliamentary Democracy: Does It Make a Difference?. In J. J. Linz and A. Valenzuela (eds), The Failure of Presidential Democracy: Comparative Perspectives. Baltimore: Johns Hopkins University Press.

Linz, J. J. (1994). Presidential or Parliamentary Democracy: Does It Make a Difference?. In J. J. Linz and A. Valenzuela (eds), The Crisis of Presidential Democracy: The Latin American Evidence. Baltimore: Johns Hopkins University Press.

Lipset, S. M. (1990). The Centrality of Political Culture. Journal of Democracy, 1(4), 81-83.

Marty, M. D. (2002). Towards a Truly Common Law: Europe as a Laboratory for Legal Pluralism. Cambridge: Cambridge University Press.

Müller, W. C. , Bergman T. \& Strom K. (2006). Parliamentary Democracy: Promise and Problems. In K. Strom (ed), Delegation and Accountability in Parliamentary Democracies. Oxford: Oxford University Press.

Onar, E. (2005). Türkiye'nin Başkanlık veya Yarı-Başkanlık Sistemine Geçmesi Düşünülmeli Midir? (Should It Be Thought for Turkey to Adopt Presidential or Semi-Presidential System?). In T. Ergül (ed), Başkanlık Sistemi (Presidential System). Ankara: Turkish Bar Association Press, 2005, p.71-104.

Öder, B.E (2005). Türkiye'de Başkanlık ve Yarı Başkanlık Rejimi Tartışmaları: 1991-2005 Yılları Arasında Basına Yansiyan Öneri ve Tepkilerden Kesitler (Debates on Presidentialism and Semi- Presidentialism in Turkey: Proposals and Criticisms as Reflected in Newspapers Between 1991-2005). In T. Ergül (ed.), Başkanlık Sistemi (Presidential System). Ankara: Turkish Bar Association Publications, p.31.

Pierson, P. (2000). Increasing Returns, Path Depedence and the Study of Politics. American Political Science Review, 94 (2), 251-267.

Sharlet, R. (1997). The Politics of Constitutional Amendment in Russia. Post-Soviet Affairs, 13 (3),197-227.

Shugart, M. S. (1993). Of Presidents and Parliaments. East European Constitutional Review, 2 (1), 30-32.

Shugart, M. S. (2005). Semi-Presidential Systems: Dual Executive and Mixed Authority Patterns. French Politics, 3 (3), 323-351.

Skach, C. (2005). Borrowing Constitutional Designs: Constitutional Law in Weimar Germany and the French Fifth Republic. Princeton, NJ: Princeton University Press.

Tanchev, E. (1993). Parliamentarism Rationalized. East European Constitutional Review, 2 (1), 33-34.

TBMMTD. (1999). The Journal of Turkish Grand National Assembly Official Reports. 21(13), 28.

Tillers, P. (2002). Introduction to Four Reviews of Breaking the Deadlock: The 2000 Election, the Constitution and the Courts. Law, Probability \& Risk, 1(1), p. 49-51.

Yavuz, H. (2000). Türkiye'de Siyasal Sistem Araylşı ve Yürütmenin Güçlendirilmesi (The Search for a Political System in Turkey and Empowerment of the Executive). Ankara: Seçkin Publishers.

\section{Notes}

Note 1. For the government system pursuit in West Europe, please see Colomer J. M. (1996). Political Institutions in Europe. London and New York: Routledge and for Russian constitutional change, please see Sharlet, R. (1997). The Politics of Constitutional Amendment in Russia. Post-Soviet Affairs, 13 (3), 197-227.

Note 2. Shugart divides the constitutional systems into 5 categories as pure presidential, premier-presidential, president-parliamentary, parliamentary with "president" and "pure" parliamentary system. Please see, Shugart, M. S. (1993). Of Presidents and Parliaments. East European Constitutional Review, 2(1), p.30.

Note 3. For this evaluation please see, Gönenç, L. (2008). Presidential Elements in Government: Turkey. European Constitutional Law Review, 4(3), p. 522.

Note 4. Cumhuriyet Newspaper, 13 April 2007, p.1; also see, “Turkish Power Balance Shifts Gül's Way”, searchable through http://news.bbc.co.uk/2/hi/europe/6951909.stm.

Note 5. As the leaders of the previous ruling parties both Turgut Özal and Süleyman Demirel, unlike Recep Tayyip Erdoğan, were nominated as presidenial candidates. 
Note 6. Abdullah Gül's wife applied to the European Court of Human Rights (ECHR) upon the rejection of her case by the Turkish Council of State for the reason that her registration had not been made by the university due to wearing headscarf although she had succeeded the university entrance exam. However, she withdrew her application after Abdullah Gül became the foreign minister in 2003. Please see, Poli Gazette, "Mrs. Gül and the Headscarf Issue", 25 April, 2007; searchable through http://www.poligazette.com/2007/04/25/mrs-gul-and-the-headscarf-issue.

Note 7. The Constitution of the Republic of Turkey, Artice 102, searchable through, http://www.anayasa.gov.tr/images/loaded/pdf_dosyalari/THE_CONSTITUTION_OF_THE_REPUBLIC_OF_TURKE Y.pdf.

Note 8. Ibid, Article 96.

Note 9. For the debates please see, Can Dündar, “Anayasa Mahkemesi’nin Kararl: 367. Şimdi Ne Olacak? (Decision of Constitutional Court: 367. What Will Happen Now?), searchable through, http://www.candundar.com.tr/index.php?Did=4876.

Note 10. Decision of the Constitutional Court, E.2007/45; K.2007/5, 01.05.2007.

Note 11. Hürriyet Gazette, "Gül Adaylıktan Çekildi” (Gül Withdrew His Candidature), 06.05.2007; searchable through http://hurarsiv.hurriyet.com.tr/goster/haber.aspx?id=6466839\&tarih=2007-05-06.

Note 12. Sabah Gazette, "Anayasa Paketi Aynen İade" (The Package of Constitutional Amendments is Returned), 31.05.2007; searchable through;

http://arsiv.sabah.com.tr/2007/05/31/haber,FF26F6A6B92040D2BB5856214B7D40D9.html.

Note 13. Decision of the Constitutional Court, E.2007/72; K.2007/68, 05.07.2007.

Note 14. Turkish electoral system has been under debate since it came into force. The main point of the discussion has been the national 10\% thresold. In 2002 elections, more than 15 parties participated in the elections; however only two parties achieved to pass the thresold and almost $45 \%$ of the electorate could not have been represented in the Turkish parliament. When a parliament constituted by this electoral system tends to change the governmental system, legitimacy discussions come into question inevitably since governmental system changes require wide based reconciliation. Not only the political parties represented in the parliament, but also the ones out of the parliament should comply with such a change.

Note 15. The right to initiate laws, the right to call referenda, decree and veto powers and the right to apply to the Constitutional Court for the review of the constitutionality of laws are included in legislative power of the president.

Note 16. The Parliamentary Governmental System can be defined as "..... system of government in which the prime minister and his or her cabinet are accountable to any majority of the members of parliament and can be voted out of office by the latter..." Please see, Müller, W. C. , Bergman T. \& Strom K. (2006). Parliamentary Democracy: Promise and Problems. In K. Strom (ed), Delegation and Accountability in Parliamentary Democracies. Oxford: Oxford University Press, p.4.

Note 17. According to Shugart, since parliamentary and parliamentary with president systems mainly show similar characteristics, they both can be studied under the rubric of parliamentary systems. Please see, Shugart, M. S. (1993). Of Presidents and Parliaments. East European Constitutional Review, 2(1), p.31. Bulgarian Constitutional System has the features of a parliamentary with president system. After the adoption of a constitutional amendment by introducing the election of the president by the people, the Slovak Constitutional System also became a parliamentary with president system.

Note 18. Duverger who introduced semi-presidentialism in the 1970 s as a means of comparing the political system of the French Fifth Republic, defined semi-presidential system as a political regime which combines three elements: 1. The president of the republic is elected by universal suffrage 2. He possesses quite considerate powers 3 . He has opposite him, however a prime minister and ministers who possess executive and governmental power and can stay in office only if the parliament does not show its opposition o them. Please see, Duverger, M. (1980). A New Political System Model: Semi-presidential Government. European Journal of Political Research, 8(2), p. 166.

Note 19. Lijphart emphasizes three major points in distinguishing between presidential and parliamentary systems. According to Lijphart, firstly, in a presidential system the head of government (the president) is elected for a fixed term and will serve this unless there is the 'unusual and exceptional process of impeachment', whereas in a parliamentary system the head of government (prime minister or equivalent) is dependent on the confidence of the legislature and thus can be removed (along with the whole government) by a motion of no-confidence. Secondly, in a presidential system the head of government (the president) is popularly elected, if not literally directly by the voters then by an electoral college popularly elected expressly for this purpose, whereas in a parliamentary system the head of government (prime minister or equivalent) is 'selected' by the legislature. Thirdly, in a presidential system there is effectively a one person 
non-collegial executive, whereas in a parliamentary system the executive (i.e., the cabinet) is collective or collegial. Please see, Lijphart, A. (1992). Introduction. In A. Lijphart (ed.), Parliamentary versus PresidentialGovernment. Oxford: Oxford University Press, p. 2-3; Lijphart, A. (1999). Patterns of Democracy: Government Forms and Performance in Thirty-Six Countries. New Haven, CT: Yale University Press, p. 17.

Note 20. The constructive vote of no confidence is also adopted by Spain, Belgium, Hungary and Poland. (Spain Constitution of 1978: Article- 113, Belgium Constitution of 1970: Article- 96, Hungary Constitution of 1949-:Article39 A, Poland Constitution of 1997-:Article- 158).

Note 21. Rationalized parliamentarism is defined as a set of constitutional devices and procedures aimed at promoting the stability of cabinets while retaining the core features of the parliamentary system, including legislative oversight of government policy. Please see Tanchev, E. (1993). Parliamentarism Rationalized. East European Constitutional Review, 2(1), p. 33.

Note 22. "The vote of confidence under dissolution threat" and "the state of legislative emergency" mechanisms included both in the German Constitution of 1949, are other significant devices of rationalized parliamentarism. Article 68 of the German Constitution of 1949 arranges the mechanism of "vote of confidence under dissolution threat". According to the article in question, if a motion of the Federal Chancellor for a vote of confidence is not supported by the majority of the Members of the Bundestag, the Federal President, upon the proposal of the Federal Chancellor, may dissolve the Bundestag within twenty-one days. The right of dissolution shall lapse as soon as the Bundestag elects another Federal Chancellor by the vote of a majority of its Members.

"The state of legislative emergency" mechanism is arranged in the article 81 of the German Constitution of 1949. Article 81 states: " 1 . If in the circumstances of article 68, the Bundestag is not dissolved, then the Federal President upon the request of the Federal Government with the consent of the Upper House of Parliament may declare a state of legislative emergency with respect to a bill if the Bundestag rejects it, although the Federal Government has called it to be urgent. 2. If after a state of legislation emergency has been declared, the Bundestag again rejects the bill or adopts it in a version the Federal Government declares unacceptable, the bill shall be deemed to have become law to the extent that it receives the consent of the Upper House of Parliament. The same shall apply if the Bundestag does not pass the bill within four weeks after it is reintroduced. 3. During the term of office of a Federal Chancellor, any other bill rejected by the Bundestag may become law in accordance with paragraphs 1 and 2 of this article within a period of six months after the first declaration of a state of legislative emergency. After the expiration of this period, no further declaration of a state of legislative emergency may be made during the term of office of the same Federal Chancellor."

As rationalized parliamentarism devices, these mechanisms are anticipated to reduce the possibility of potential governmental instability. Turkey could have been adopted similar mechanisms to reduce the possibility of its potential governmental instability.

Note 23. Ahmet Necdet Sezer exercised his veto power 72 times, including one constitutional amendment. Please see, Bahçeci, B. (2008). Karşılaş̧ırmalı Hukukta ve Türkiye'de Devlet Başkanının Veto Yetkisi (President's Veto Power in Comparative Law and in Turkey). Ankara: Yetkin Publishers, p. 222-230.

Note 24. His speech was delivered at the opening ceremony of the 37th anniversary of the establishment of Constitutional Court. For the full text of the speech in Turkish, see The Official Website of the Constitutional Court of Turkey, searchable through,

$<$ http://www.anayasa.gov.tr/general/icerikler.asp?contID $=267 \&$ menuID $=64>$. 